\title{
Fatty acid profiles of varietal virgin olive oils (Olea europaea L.) from mature orchards in warm arid valleys of Northwestern Argentina (La Rioja)
}

\author{
By D.P. Rondanini ${ }^{\star}$, D.N. Castro, P.S. Searles, and M.C. Rousseaux \\ CRILAR-CONICET, Entre Ríos y Mendoza s/n (5301) Anillaco, La Rioja, Argentina. \\ Tel: +54 3827 494251, Fax: +54 3827454231 \\ ( ${ }^{*}$ corresponding author: rondanin @agro.uba.ar)
}

\section{RESUMEN}

Perfiles de ácidos grasos de aceites de oliva virgen (Olea europaea L.) de huertos en plena producción en los valles cálidos áridos del noroeste de Argentina (La Rioja).

La industria oleícola del noroeste de Argentina creció sustancialmente durante las últimas dos décadas para producir aceite de oliva virgen exportable. Para evaluar el perfil de ácidos grasos de los principales aceites varietales, se analizaron 563 muestras de aceite de 17 variedades en la provincia de La Rioja durante 2005-2008. Las variedades se clasificaron de acuerdo a su contenido de ácido oleico en bajo ( $<55 \%$; Arbequina, Arauco), medio (55-65\%; Barnea, Frantoio), o alto ( $>65 \%$; Manzanilla, Empeltre, Leccino, Coratina, Changlot, Picual). Utilizando datos de este trabajo y de la literatura, los aceites de variedades de origen español (Arbequina y Picual) e italiano (Coratina y Frantoio) mostraron consistentemente menor contenido de ácido oleico cuando crecieron en el noroeste de Argentina versus el Mediterráneo. Para Arbequina, el contenido de oleico disminuyó con la temperatura durante la síntesis y acumulación lipídica $(-2 \%$ por ${ }^{\circ} \mathrm{C}$ ). La clasificación varietal por acido oleico debe ser útil para seleccionar aceites para mezclas correctivas y variedades para futuras plantaciones que cumplan con la normativa del COI. Diferencias en los perfiles de ácidos grasos entre el noroeste de Argentina y el Mediterráneo indican una interacción genotipo $x$ ambiente, y el efecto negativo de la alta temperatura media estacional durante la síntesis de lípidos requerirá mayor investigación.

PALABRAS CLAVE: Aceite de oliva virgen - Ácido oleico - Ambiente árido cálido - Calidad del aceite - Temperatura.

\section{SUMMARY}

Fatty acid profiles of varietal virgin olive oils (Olea europaea L.) from mature orchards in warm arid valleys of Northwestern Argentina (La Rioja).

The olive industry in Northwestern Argentina has experienced substantial growth during the past two decades to produce virgin olive oil for export. To assess the fatty acid profiles of the main varietal olive oils, 563 oil samples from 17 varieties cultivated in the province of La Rioja were analyzed from 2005-2008. Olive varieties were ranked according to oleic acid content as low ( $<55 \%$; Arbequina, Arauco), intermediate (55-65\%; Barnea, Frantoio) or high (>65\%; Manzanilla, Empeltre, Leccino, Coratina, Changlot, Picual). Using data from this study and the literature, the fatty acid composition of Spanish (Arbequina, Picual) and Italian (Coratina, Frantoio) varieties indicated consistently lower oleic acid contents when grown in NW Argentina versus the Mediterranean. For Arbequina, the oleic content decreased with increasing temperature during oil accumulation $\left(-2 \%\right.$ per $\left.{ }^{\circ} \mathrm{C}\right)$. The classification of varieties should be useful in the selection of virgin olive oils for corrective blending and for choosing varieties for new orchards in order to meet IOOC requirements. The differences in fatty acid composition between NW Argentina and the Mediterranean Basin are most likely to be related to a genotype $x$ environment interaction, and the negative effect of the high seasonal mean temperature during oil accumulation will need further research.

KEY-WORDS: Oil quality - Oleic acid - Temperature Virgin olive oil - Warm arid environment.

\section{INTRODUCTION}

In the last two decades, olive production has increased dramatically in Argentina due to governmental tax promotions spurred by the increased international demand for olive oil. New orchards have been planted in the warm desert valleys of mountainous Northwestern Argentina including the Provinces of La Rioja, Catamarca, and San Juan (28 $-31^{\circ} \mathrm{S}$ latitude). This extensive region covers about $25,000 \mathrm{~km}^{2}$ and has a great deal of environmental variability in temperature, rainfall, elevation above sea level, and soils (Ayerza and Sibbett, 2001). The climate is semi-arid to arid with higher temperatures (especially in the winter and spring) than in the Mediterranean Basin, and rainfall occurs predominately in the summer months with a pronounced dry season in the winter. The new olive industry mainly consists of large private growers and investors with intensive mono-varietal orchards including both table and oil varieties from Italy and Spain along with some production of the local Argentine variety Arauco (Matías et al., 2004). Domestic olive oil consumption is very low, and olive oil is mainly exported to Brazil, Canada, the United States, and some European countries (MAGPyA, 2010).

The increase in olive production has been accompanied by a modernization of the industrial extraction facilities. Modern facilities have been installed with the primary aim of producing high quality virgin olive oils rather than refining or extracting oil with solvent from olive-pomace. The 
industry mainly uses continuous systems with two-phase centrifuge decanters. Most olives are harvested by hand from March to June (i.e., late summer to autumn) after the summer rainy season although an increasing proportion of the orchards are harvested mechanically.

The definition of olive oil quality is complex and variable because it depends on consumer evaluation of chemical and sensorial attributes (Civantos, 1999). Trade standards on olive oil have designated specific chemical criteria including the fatty acid profile for determining the quality and purity of olive oil (IOOC, 2006). Such criteria were formed primarily based on the composition of olive oils from the Mediterranean Basin. However, the chemical parameters of olive oils produced in other areas may not always enter into these accepted ranges. While olive variety is the major determinant of chemical oil composition, environmental factors such as temperature during fruit growth also play a role in oil quality (Uceda and Hermoso, 2001). Environmental factors have likely contributed to some of the differences in the fatty acid composition found in Tunisia (Dhifi et al., 2004; Manaï et al., 2007; Zarrouk et al., 2009), Turkey (Nergiz and Engez, 2000), Iran (Sadeghi and Talaii, 2002), and Australia (Mailer, 2005) compared to traditional European producers.

In Argentina, olive varieties from the Mediterranean Basin, mainly from Spain and Italy, have been selected due to their acceptance on the world market with the expectation that they will perform similarly in their new environment. Some early evidence for specific geographic zones such as Catamarca in NW Argentina indicated that the chemical composition of olive oils from some Mediterranean varieties often includes low levels of oleic acid and high linoleic acid (Ravetti, 1999; Mannina et al., 2001; Ravetti et al., 2002; Ceci et al., 2004). Thus, olive oils from warm valleys in NW Argentina may not necessarily pass the required purity analyses used for acceptance as virgin olive oil (Ceci and Carelli, 2007; Torres et al., 2009; Ceci and Carelli, 2010).

The chemical characterization of olive oils in NW Argentina is still relatively limited, and a greater understanding of olive oils from non-Mediterranean regions is essential considering the increasingly global nature of the olive industry. Previous studies from NW Argentina evaluated samples $(<50)$ primarily from young trees ( $<10$ years-old) because older, mature trees were not yet available for many varieties (Mannina et al., 2001; Ravetti et al., 2002; Ceci et al., 2004). To the best of our knowledge, there are no detailed studies on fatty acid composition over several consecutive years in NW Argentina with a large number of samples $(>500)$ obtained from mature, intensively managed orchards. Additionally, the provinces of La Rioja and Catamarca currently represent about 50,000 of the 90,000 ha planted in Argentina and their industrial facilities often process fruits from neighboring provinces. The primary objectives of this study were to: i) assess the fatty acid profiles of
17 olive varieties in NW Argentina over four years (2005- 2008) based on 563 oil samples from the province of La Rioja and surrounding areas in order to rank the varieties by oleic acid content; and ii) compare fatty acid performance from the region with that of the Mediterranean Basin using data from the literature. Secondarily, the influence of temperature on oleic acid content was considered.

\section{MATERIALS AND METHODS}

\subsection{Oil samples}

Samples of virgin olive oil (Table 1) were obtained from ten commercial olive oil extraction facilities in the Province of La Rioja. The oil samples provided by these facilities were primarily from fruit harvested in orchards located in La Rioja although some oil samples from fruits harvested at other geographical locations, but extracted in La Rioja, were also provided by these same facilities. The overall olive growing area that the samples represented was $27^{\circ}-31^{\circ} \mathrm{S}$ latitude and $64^{\circ}-68^{\circ} \mathrm{W}$ longitude. This area includes a significant range of mean temperature and elevation above sea level due to the mountainous terrain (Table 2). The extraction facilities provided tracking information such as variety, area of origin, date of milling, and fruit maturity for all samples (except for fruit maturity in 2006). The fruit maturity index was defined according to Uceda and Hermoso (2001) with $0=$ brilliant green to $7=$ skin and pulp completely black). The harvest season was from March 25 July 2 in 2005, April 4 - May 30 in 2006, February 28 - June 13 in 2007 and March 19 - June 4 in 2008. Seventeen olive varieties were assessed, but Arbequina represented $57 \%$ of all the samples because it is the most frequently planted oil variety in NW Argentina. Arbequina was followed by Barnea (10\%), Frantoio (7\%), Manzanilla (6\%) and Picual (5\%). Oil samples were obtained directly from the production line at the vertical centrifuge, from two-phase continuous extraction systems with temperature and time of milling typically ranging from $30-34^{\circ} \mathrm{C}$ and $40-60$ minutes, respectively. Oil was collected in $300-\mathrm{mL}$ glass bottles without air space. After decantation of impurities (about a month), the samples were passed to clean glass bottles and stored in the laboratory at room temperature, in the dark until analysis.

\subsection{Chemical analysis}

The fatty acid composition of the oils was determined by gas chromatography in the Natural Products Laboratory of CRILAR-CONICET, following the analytical methods described in the Regulations of the Commission of the European Union (EEC 2568/91). Fatty acid methyl esters were prepared by cold transmethylation in a basic medium (IOOC, 2001) and were separated in an HP 5890 II gas chromatograph (Hewlett-Packard, Sacramento, CA) 
Table 1

Origin of virgin olive oil samples analyzed

\begin{tabular}{|c|c|c|c|c|}
\hline Year & Locations & Facilities $^{a}$ & Varieties & $\begin{array}{l}\text { Range of } \\
\text { Maturity index }\end{array}$ \\
\hline $\begin{array}{l}2005 \\
(15)^{b}\end{array}$ & $\begin{array}{l}\text { Aimogasta (5), Chilecito (1), La Rioja (2), } \\
\text { Pomán (4), San Juan (1), Cruz del Eje (2) }\end{array}$ & A (15) & $\begin{array}{l}\text { Arauco (1) } \\
\text { Arbequina (11) } \\
\text { Barnea (1) } \\
\text { Coratina (1) } \\
\text { Frantoio (1) }\end{array}$ & $\begin{array}{l}2.1 \\
1.6-5.5 \\
2.6 \\
1.9 \\
1.9\end{array}$ \\
\hline $\begin{array}{l}2006 \\
(105)\end{array}$ & $\begin{array}{l}\text { Aimogasta (30), Andalgalá (2), Cruz del Eje } \\
\text { (1), La Rioja (62), Tinogasta (5), Valle } \\
\text { Central Catamarca (2), Villa Mazán (3) }\end{array}$ & A (92), B (6), C (7) & $\begin{array}{l}\text { Arauco (12) } \\
\text { Arbequina (54) } \\
\text { Barnea (19) } \\
\text { Carolea (1) } \\
\text { Coratina (1) } \\
\text { Empeltre (5) } \\
\text { Frantoio (1) } \\
\text { Manzanilla (7) } \\
\text { Picual (5) }\end{array}$ & $\begin{array}{l}\text { nd } \\
\text { nd } \\
\text { nd } \\
\text { nd } \\
\text { nd } \\
\text { nd } \\
\text { nd } \\
\text { nd } \\
\text { nd }\end{array}$ \\
\hline $\begin{array}{l}2007 \\
(226)\end{array}$ & $\begin{array}{l}\text { Aimogasta (78), Chilecito (45), Chumbicha } \\
\text { (3), La Rioja (86), Pomán (5), San Juan (2), } \\
\text { Valle Central Catamarca (3),Villa Mazán (4) }\end{array}$ & $\begin{array}{l}A(83), B(21), C \\
(1), D(49), E(32) \\
F(26), G(11), H(3)\end{array}$ & $\begin{array}{l}\text { Arauco (9) } \\
\text { Arbequina (157) } \\
\text { Barnea (17) } \\
\text { Changlot real (2) } \\
\text { Coratina (8) } \\
\text { Empeltre (4) } \\
\text { Frantoio (10) } \\
\text { Leccino (1) } \\
\text { Manzanilla (11) } \\
\text { Picual (7) }\end{array}$ & $\begin{array}{l}3.0-3.4 \\
1.9-4.8 \\
2.9-3.6 \\
3.7-3.8 \\
1.3-1.8 \\
\text { nd } \\
2.5-3.6 \\
3.6 \\
2.3-4.8 \\
1.5-4.2\end{array}$ \\
\hline $\begin{array}{l}2008 \\
(217)\end{array}$ & $\begin{array}{l}\text { Aimogasta (27), Chilecito (15), La Rioja } \\
\text { (156), Valle Central Catamarca (11), } \\
\text { Tinogasta (5), Villa Mazán (3) }\end{array}$ & $\begin{array}{l}A(67), B(4), C \text { (1), } \\
D(4), E(84), F \\
(32), G(4), H(5), I \\
(5), J(11)\end{array}$ & $\begin{array}{l}\text { Arauco (4) } \\
\text { Arbequina (98) } \\
\text { Arbosana (2) } \\
\text { Barnea (19) } \\
\text { Changlot real (5) } \\
\text { Coratina (4) } \\
\text { Farga (2) } \\
\text { Frantoio (29) } \\
\text { Hojiblanca (1) } \\
\text { Leccino (11) } \\
\text { Manzanilla (19) } \\
\text { Nabali (1) } \\
\text { Peranzana (1) } \\
\text { Picual (20) } \\
\text { Sirio (1) }\end{array}$ & $\begin{array}{l}\text { nd } \\
2.4-4.5 \\
4.0-4.2 \\
2.8-3.4 \\
2.9-3.7 \\
1.5-1.6 \\
3.1-3.7 \\
2.2-4.9 \\
\text { nd } \\
3.7-5.2 \\
2.2-4.2 \\
\text { nd } \\
\text { nd } \\
2.7-4.4 \\
\text { nd }\end{array}$ \\
\hline
\end{tabular}

\footnotetext{
${ }^{a}$ The olive oil extraction facilities are named using an alphabetical code.

${ }^{b}$ The number of samples per year, location, variety and facility are given in parenthesis. nd data not available
}

fitted with a 25-m capillary column (CP-Wax 52 CB; Chrompack, Holland) with a $0.32 \mathrm{~mm}$ I.D., $0.25 \mu \mathrm{m}$ film thickness and equipped with split injection and an FID detector. Hydrogen was the carrier gas, and injector and detector temperatures were set to 250 and $300^{\circ} \mathrm{C}$, respectively. Oven temperature was programmed at $180^{\circ} \mathrm{C}$ for $5 \mathrm{~min}$, increased from 180 to $240^{\circ} \mathrm{C}$ at $4^{\circ} \mathrm{C} \mathrm{min}^{-1}$, and then was set at $240^{\circ} \mathrm{C}$ for $10 \mathrm{~min}$. Individual fatty acids (myristic, palmitic, palmitoleic, heptadecanoic, heptadecenoic, stearic, oleic, linoleic, linolenic, arachidic, arachidonic, behenic and lignoceric acids) were determined by comparison with retention times of known standards (AOCS-1, Sigma-Aldrich, St. Louis, MO).

\subsection{Bibliographic data}

Data of fatty acid compositions (palmitic, stearic, oleic, linoleic and linolenic acids) were obtained from the published literature for the Spanish varieties Arbequina and Picual and the Italian varieties Coratina and Frantoio for several regions of Spain and Italy (Table 3). The data correspond to oils from fruit harvested at their typical harvesting time (variable between areas and production systems), and the fruit maturity index is given when available. Studies without maturity index data were included in order to have sufficient data to facilitate comparisons. The fatty acid data from Spain and 
Table 2

Characteristics of the olive production areas in NW Argentina used in this study

\begin{tabular}{|c|c|c|c|c|c|}
\hline Province & Location & $\begin{array}{l}\text { Latitude } \\
\qquad\left({ }^{\circ} \mathrm{S}\right)\end{array}$ & $\begin{array}{l}\text { Longitude } \\
\qquad\left({ }^{\circ} \mathrm{W}\right)\end{array}$ & $\begin{array}{l}\text { Elevation } \\
\qquad(\mathrm{m})\end{array}$ & $\begin{array}{l}\text { Average mean temperature } \\
\text { during oil accumulation }\left({ }^{\circ} \mathrm{C}\right)\end{array}$ \\
\hline \multirow[t]{4}{*}{ La Rioja } & Aimogasta & $28^{\circ} 34^{\prime}$ & $66^{\circ} 46^{\prime}$ & 800 & $24.4 \pm 0.5$ \\
\hline & Chilecito & $29^{\circ} 38^{\prime}$ & $67^{\circ} 24^{\prime}$ & 850 & $23.7 \pm 0.3$ \\
\hline & La Rioja City & $29^{\circ} 33^{\prime}$ & $66^{\circ} 49^{\prime}$ & 420 & $25.2 \pm 0.9$ \\
\hline & Villa Mazán & $28^{\circ} 40^{\prime}$ & $66^{\circ} 33^{\prime}$ & 654 & nd \\
\hline \multirow[t]{5}{*}{ Catamarca } & Andalgalá & $27^{\circ} 36^{\prime}$ & $66^{\circ} 20^{\prime}$ & 1018 & nd \\
\hline & Chumbicha & $28^{\circ} 52^{\prime}$ & $66^{\circ} 14^{\prime}$ & 429 & nd \\
\hline & Valle Central & $28^{\circ} 36^{\prime}$ & $65^{\circ} 46^{\prime}$ & 450 & $25.8 \pm 0.7$ \\
\hline & Pomán & $28^{\circ} 23^{\prime}$ & $66^{\circ} 13^{\prime}$ & 820 & $25.1 \pm 0.5$ \\
\hline & Tinogasta & $28^{\circ} 03^{\prime}$ & $67^{\circ} 34^{\prime}$ & 1212 & $23.6 \pm 0.5$ \\
\hline San Juan & San Juan & $31^{\circ} 31^{\prime}$ & $68^{\circ} 33^{\prime}$ & 630 & $23.9 \pm 0.4$ \\
\hline Córdoba & Cruz del Eje & $30^{\circ} 43^{\prime}$ & $64^{\circ} 48^{\prime}$ & 460 & nd \\
\hline
\end{tabular}

${ }^{a}$ Average mean temperature \pm SD from December to April on 4 years (2005-2008).

nd data not available

Table 3

Studies from NW Argentina and the Mediterranean region used for linear discriminate analysis and tree cluster analysis of fatty acid composition in four olive varieties

\begin{tabular}{|c|c|c|c|}
\hline Location & Olive variety & Maturity index & Reference \\
\hline Catamarca, Argentina & $\begin{array}{l}\text { Arbequina } \\
\text { Frantoio } \\
\text { Coratina }\end{array}$ & $\begin{array}{l}\mathrm{nd}^{\mathrm{a}} \\
\mathrm{nd} \\
\text { nd }\end{array}$ & Mannina et al. 2001 \\
\hline Catamarca, Argentina & $\begin{array}{l}\text { Arbequina } \\
\text { Picual }\end{array}$ & $\begin{array}{l}1-3.5 \\
1-2\end{array}$ & Matías et al. 2004 \\
\hline Córdoba, Argentina & Arbequina & nd & Torres and Maestri 2006 \\
\hline Central Italy & $\begin{array}{l}\text { Frantoio } \\
\text { Coratina }\end{array}$ & $\begin{array}{l}\text { nd } \\
\text { nd }\end{array}$ & Mannina et al. 2001 \\
\hline Lazio, Italy & Frantoio & nd & Bucci et al. 2002 \\
\hline Pescara, Italy & Frantoio & $1-4$ & Ranalli et al. 1998 \\
\hline Pescara, Italy & Coratina & nd & Ranalli et al. 1999 \\
\hline Puglia, Italy & Coratina & nd & Di Giovacchino et al. 2002 \\
\hline Ciudad Real, Spain & $\begin{array}{l}\text { Arbequina } \\
\text { Picual }\end{array}$ & $\begin{array}{l}\text { nd } \\
\text { nd }\end{array}$ & Pardo et al. 2007 \\
\hline Córdoba, Spain & $\begin{array}{l}\text { Arbequina } \\
\text { Frantoio } \\
\text { Picual }\end{array}$ & $\begin{array}{l}1.8 \\
2.2 \\
2.8\end{array}$ & Civantos 1999 \\
\hline Córboba, Spain & $\begin{array}{l}\text { Arbequina } \\
\text { Picual }\end{array}$ & $\begin{array}{l}5 \\
5\end{array}$ & Sánchez-Ortiz et al. 2007 \\
\hline Jaén, Spain & $\begin{array}{l}\text { Arbequina } \\
\text { Frantoio } \\
\text { Picual }\end{array}$ & $\begin{array}{l}\text { nd } \\
\text { nd } \\
\text { nd }\end{array}$ & Uceda and Hermoso 2001 \\
\hline Jaén, Spain & Picual & $1-3.5$ & Beltrán et al. 2004 \\
\hline Jaén \& Córdoba, Spain & Frantoio & 3 & Aguilera et al. 2005 \\
\hline Lleida, Spain & Arbequina & nd & Tovar et al. 2002 \\
\hline Lleida, Spain & Arbequina & nd & Morelló et al. 2004 \\
\hline
\end{tabular}

${ }^{a}$ nd: no data indicated in the bibliographic source 
Italy were contrasted to the observed values for the same varieties growing in La Rioja and other locations in Northwest Argentina including values from this study and published values from the literature (Tables 1, 3).

\subsection{Statistical analysis}

Descriptive statistics were performed using the Infostat software package (Infostat, Universidad de Córdoba, Argentina) and data on fatty acid composition are presented as means \pm standard deviations. Pearson correlation coefficients were also calculated between individual fatty acids and year, latitude, longitude, elevation, fruit maturity index, location and variety. Categorical variables (i.e., location, variety) were transformed into discrete numeric values when necessary. Linear regression was fitted to the relationships between linoleic, palmitic and oleic acid. The temperature response of oleic acid content in Arbequina was analyzed by regressing the oleic acid content of each location by year combination with seasonal mean temperature during the oil accumulation period (i.e., the monthly mean temperature from December to April in the Southern Hemisphere).

Linear discriminate analysis (LDA) and tree cluster analysis (TCA) were applied to fatty acid compositions (palmitic, stearic, oleic, linoleic and linolenic acids) of four olive varieties growing in NW Argentina and the Mediterranean region based on data from this study (Table 1) and the published literature (Table 3). The LDA method determines which variables discriminate between two or more a priori defined groups. In our case, the a priori groups were each olive variety from NW Argentina or the Mediterranean region (i.e., 8 groups in total). The selected variables were used to obtain a data matrix (dissimilarities matrix) and a discriminant (canonical) linear equation. The discriminator power of each variable was evaluated using Wilki's lambda factor. The TCA method joins objects into successively large clusters using some measure of distance. We used the dissimilarity matrix from Mahalanobis distances, and the unweighted pairgroup average was used as the amalgamation rule.

\section{RESULTS}

\subsection{Fatty acid profile of varietal virgin olive oils from NW Argentina}

The fatty acid compositions of the oil samples depended mainly on olive variety (Table 4). Year, location, latitude, longitude, elevation, and oil facility did not show significant correlations with individual fatty acids when data from all varieties were considered (Table 4), nor did the fruit maturity index in the 235 samples that included this information $(r=$ $0.09, p=0.38$ ). The wide range of oleic acid values observed in Table 5 permitted the classification of varieties as low $(<55 \%)$, intermediate $(55-65 \%)$ or high $(>65 \%)$ in oleic acid contents. The lowest mean oleic acid values were found in the Spanish variety Arbequina $(51.8 \%, \mathrm{~N}=320)$ and the Argentine variety Arauco $(54.9 \%, \mathrm{~N}=26)$, while the highest mean corresponded to Picual $(71.9 \%$, $\mathrm{N}=32$ ). Intermediate oleic acid values were found in Barnea and Frantoio. Manzanilla, Leccino, Empeltre, Changlot and Coratina had high values as well as Picual. This classification was stable between years and locations and was not a function of differences in maturity index between varieties. For example, Picual and Arbequina had a similar average maturity index (3.4 and 3.1 , respectively) and had the most contrasting oleic acid values (Table 5). Varieties with only 1-2 samples over the 4 years were not classified.

Negative linear relationships were observed between oleic and linoleic acids when including all varieties, locations and years (linoleic $=55.3$ - 0.64*oleic; $r^{2}=0.90 ; p<0.0001$ ). Oleic and palmitic acids also showed a strong negative linear relationship for all samples (palmitic= $34.0-0.29^{*}$ oleic; $\left.r^{2}=0.78 ; p<0.0001\right)$. Similar relationships were apparent when varieties were evaluated individually (Fig. 1). Thus, varieties with low oleic acid values such as Arbequina and Arauco showed concomitantly high levels of linoleic and palmitic acids. By contrast, varieties with high oleic acid contents such as Picual, Changlot and Coratina had low levels of linoleic and palmitic acids. For linolenic acid, $25 \%$ of oil samples exceeded the IOOC limit of $1.0 \%$ needed

Table 4

Correlation coefficients ( $r$ ) between fatty acid composition and variety, year, location, latitude, longitude, elevation, or oil facility for olive oil samples from NW Argentina

\begin{tabular}{lccccccc}
\hline Fatty acid & Variety & Year & Location & Latitude & Longitude & Elevation & Facility \\
\hline Palmitic (16:0) & $-0.62^{*}$ & -0.15 & -0.18 & -0.24 & -0.13 & 0.07 & -0.07 \\
Palmitoleic (16:1) & $-0.53^{*}$ & -0.10 & -0.01 & -0.03 & -0.09 & -0.09 & -0.09 \\
Stearic (18:0) & $0.58^{*}$ & 0.10 & 0.03 & 0.02 & -0.10 & -0.07 & -0.01 \\
Oleic (18:1) & $0.77^{*}$ & 0.25 & 0.15 & 0.17 & 0.07 & -0.07 & 0.15 \\
Linoleic (18:2) & $-0.80^{*}$ & -0.27 & -0.13 & -0.13 & 0.00 & 0.09 & -0.17 \\
Linolenic (18:3) & 0.18 & -0.10 & 0.00 & -0.03 & -0.22 & -0.18 & 0.00 \\
\hline
\end{tabular}

Asterisks indicate correlation with significant slope $(p<0.05)$. 
Table 5

Fatty acid composition (\%) and fruit maturity index of olive oil varieties from NW Argentina (2005 - 2008) in order of ascending oleic acid content

\begin{tabular}{|c|c|c|c|c|c|c|c|c|c|c|c|c|}
\hline $\begin{array}{l}\text { Olive } \\
\text { variety }\end{array}$ & $\mathrm{N}^{\mathrm{a}}$ & $\begin{array}{l}\text { Oleic } \\
(\%)\end{array}$ & $\begin{array}{l}\text { Linoleic } \\
(\%)\end{array}$ & $\begin{array}{l}\text { Linolenic } \\
(\%)\end{array}$ & $\begin{array}{l}\text { Palmitic } \\
(\%)\end{array}$ & $\begin{array}{c}\text { Stearic } \\
(\%)\end{array}$ & $\begin{array}{l}\text { Palmitoleic } \\
(\%)\end{array}$ & $\begin{array}{l}\text { Arachidic } \\
(\%)\end{array}$ & $\begin{array}{l}\text { Arachidonic } \\
(\%)\end{array}$ & $\begin{array}{c}\text { Behenic } \\
(\%)\end{array}$ & $\begin{array}{l}\text { Lignoceric } \\
(\%)\end{array}$ & $\begin{array}{c}\text { Maturity } \\
\text { index }\end{array}$ \\
\hline Arbequina & 320 & $51.8 \pm 4.1^{b}$ & $21.9 \pm 2.8$ & $1.0 \pm 0.1$ & $19.2 \pm 1.3$ & $1.6 \pm 0.1$ & $3.3 \pm 0.7$ & $0.4 \pm 0.05$ & $0.2 \pm 0.03$ & $0.1 \pm 0.05$ & $0.1 \pm 0.12$ & $3.1 \pm 0.6$ \\
\hline Peranzana & 1 & 53.2 & 22.9 & 1.3 & 17.3 & 2.1 & 1.9 & 0.5 & 0.3 & 0.2 & 0.1 & 1.0 \\
\hline Nabali & 1 & & & & & & & & & & & 1.5 \\
\hline Arauco & 26 & $54.9 \pm 3.1$ & $19.1 \pm 2.1$ & $1.1 \pm 0.2$ & $18.2 \pm 0.9$ & $2.6 \pm 0.3$ & $2.2 \pm 0.3$ & $0.5 \pm 0.03$ & $0.2 \pm 0.02$ & $0.2 \pm 0.06$ & $0.7 \pm 0.32$ & $2.7 \pm 1.0$ \\
\hline Farga & 2 & $59.4 \pm 0.6$ & $16.2 \pm 0.8$ & $1.2 \pm 0.1$ & $18.5 \pm 0.2$ & $1.6 \pm 0.01$ & $2.3 \pm 0.04$ & $0.4 \pm 0.01$ & $0.3 \pm 0.01$ & $0.1 \pm 0.01$ & $0.1 \pm 0.02$ & $3.4 \pm 0.5$ \\
\hline Arbosana & 2 & $61.0 \pm 0.8$ & $15.6 \pm 1.0$ & $0.9 \pm 0.1$ & $16.5 \pm 0.3$ & $2.0 \pm 0.4$ & $2.8 \pm 0.2$ & $0.4 \pm 0.02$ & $0.3 \pm 0.01$ & $0.2 \pm 0.02$ & $0.1 \pm 0.01$ & $4.2 \pm 0.1$ \\
\hline Barnea & 56 & $61.0 \pm 2.1$ & $19.8 \pm 1.7$ & $0.9 \pm 0.1$ & $13.6 \pm 1.0$ & $2.1 \pm 0.2$ & $1.3 \pm 0.3$ & $0.4 \pm 0.02$ & $0.2 \pm 0.02$ & $0.1 \pm 0.05$ & $0.3 \pm 0.15$ & $3.2 \pm 0.3$ \\
\hline Carolea & 1 & 62.5 & 11.9 & 0.8 & 17.7 & 2.3 & 2.5 & 0.5 & 0.3 & 0.1 & 0.8 & $\mathrm{nd}^{\mathrm{c}}$ \\
\hline Sirio & 1 & 62.8 & 16.2 & 0.8 & 14.0 & 3.8 & 1.0 & 0.5 & 0.3 & 0.2 & 0.1 & $\mathrm{nd}^{\mathrm{c}}$ \\
\hline Frantoio & 41 & $63.1 \pm 2.1$ & $15.3 \pm 1.8$ & $1.0 \pm 0.1$ & $15.4 \pm 0.8$ & $2.3 \pm 0.3$ & $1.6 \pm 0.1$ & $0.4 \pm 0.02$ & $0.3 \pm 0.02$ & $0.1 \pm 0.03$ & $0.1 \pm 0.09$ & $3.0 \pm 0.7$ \\
\hline Manzanilla & 37 & $65.3 \pm 7.0$ & $11.6 \pm 5.4$ & $1.1 \pm 0.2$ & $15.9 \pm 1.4$ & $2.3 \pm 0.8$ & $2.2 \pm 0.4$ & $0.4 \pm 0.10$ & $0.3 \pm 0.04$ & $0.1 \pm 0.03$ & $0.3 \pm 0.27$ & $3.4 \pm 0.8$ \\
\hline Empeltre & 9 & $65.5 \pm 4.7$ & $12.8 \pm 4.0$ & $1.2 \pm 0.1$ & $15.7 \pm 1.1$ & $1.9 \pm 0.4$ & $1.2 \pm 0.5$ & $0.4 \pm 0.06$ & $0.3 \pm 0.03$ & $0.1 \pm 0.04$ & $0.3 \pm 0.19$ & $n d^{c}$ \\
\hline Leccino & 12 & $67.5 \pm 2.3$ & $11.9 \pm 2.0$ & $0.9 \pm 0.1$ & $14.8 \pm 0.5$ & $2.4 \pm 0.4$ & $1.5 \pm 0.1$ & $0.3 \pm 0.02$ & $0.3 \pm 0.01$ & $0.1 \pm 0.02$ & $0.1 \pm 0.05$ & $4.2 \pm 0.5$ \\
\hline Coratina & 14 & $68.9 \pm 2.3$ & $12.9 \pm 1.6$ & $0.9 \pm 0.1$ & $12.9 \pm 1.4$ & $2.1 \pm 0.2$ & $0.7 \pm 0.3$ & $0.4 \pm 0.03$ & $0.5 \pm 0.03$ & $0.1 \pm 0.02$ & $0.4 \pm 0.21$ & $1.6 \pm 0.2$ \\
\hline Changlot & 7 & $69.1 \pm 0.9$ & $11.8 \pm 0.7$ & $0.9 \pm 0.1$ & $13.4 \pm 0.4$ & $2.0 \pm 0.1$ & $1.0 \pm 0.1$ & $0.4 \pm 0.02$ & $0.5 \pm 0.02$ & $0.1 \pm 0.01$ & $0.3 \pm 0.30$ & $3.5 \pm 0.3$ \\
\hline Hojiblanca & 1 & 69.8 & 8.0 & 1.3 & 15.8 & 2.2 & 1.4 & 0.4 & 0.3 & 0.2 & 0.2 & $\mathrm{nd}^{\mathrm{c}}$ \\
\hline Picual & 32 & $71.9 \pm 3.0$ & $7.7 \pm 2.1$ & $1.0 \pm 0.1$ & $13.8 \pm 0.8$ & $2.5 \pm 0.3$ & $1.7 \pm 0.3$ & $0.4 \pm 0.03$ & $0.3 \pm 0.02$ & $0.1 \pm 0.04$ & $0.4 \pm 0.36$ & $3.4 \pm 0.7$ \\
\hline
\end{tabular}

${ }^{a}$ Number of samples per variety

${ }^{\mathrm{b}}$ Values are means $\pm \mathrm{SD}$

${ }^{\mathrm{c}}$ nd data not available

for categorization as virgin olive oil with Empeltre, Manzanilla and Arauco varieties having the highest mean values (Table 5).

\subsection{Response of oleic acid content to temperature in Arbequina}

Oleic acid values in Arbequina were significantly associated $\left(r^{2}=0.59 ; p<0.0005\right)$ with seasonal mean temperature during oil accumulation for the 6 locations in La Rioja and Catamarca where reliable meteorological data were available (Fig. 2). Interestingly, the relationship is negative, indicating that oleic acid decreased 2 percentage points per ${ }^{\circ} \mathrm{C}$ in the range of seasonal mean temperatures from $23-27^{\circ} \mathrm{C}$. Some apparently negative relationships between oleic acid content and temperature were observed in other varieties, but with a lesser number of years and locations than Arbequina (data not shown).

\subsection{Comparison between NW Argentina and the Mediterranean Basin}

The values of oleic acid from this study and others conducted in NW Argentina were lower than those reported from the Mediterranean basin for two Italian and two Spanish varieties (Fig. 3). As would be expected, linoleic acid (\%) was thus higher in NW Argentina. Linear discriminant analysis applied to 5 variables (palmitic, stearic, oleic, linoleic and linolenic acids) indicated that oleic, linoleic, and palmitic acids provided the highest discriminating power. Classifications between the 4 varieties $\times 2$ growing regions were successful in $>95 \%$ of cases. Mahalanobis distances ranged from 4.3 between Frantoio and Coratina in the Mediterranean to 69.2 between Arbequina in Argentina and Picual in the Mediterranean. All of the distances were significantly different $(p<0.01)$ except between Frantoio and Coratina in the Mediterranean $(p=0.06)$. The tree cluster analysis (Fig. 4) indicated that Arbequina cultivated in NW Argentina was completely different from all of the other combinations of variety and growing region (cutting the dendrogram at the first level) due to low oleic acid content and high levels of palmitic and linoleic acids. By cutting the dendrogram at the second level, two additional groupings were apparent: one including Picual from both Argentina and the Mediterranean, and another including the rest of the varieties. The results indicate that of the four varieties evaluated only Picual produced an olive oil with a similar fatty acid composition in NW Argentina and the Mediterranean. 

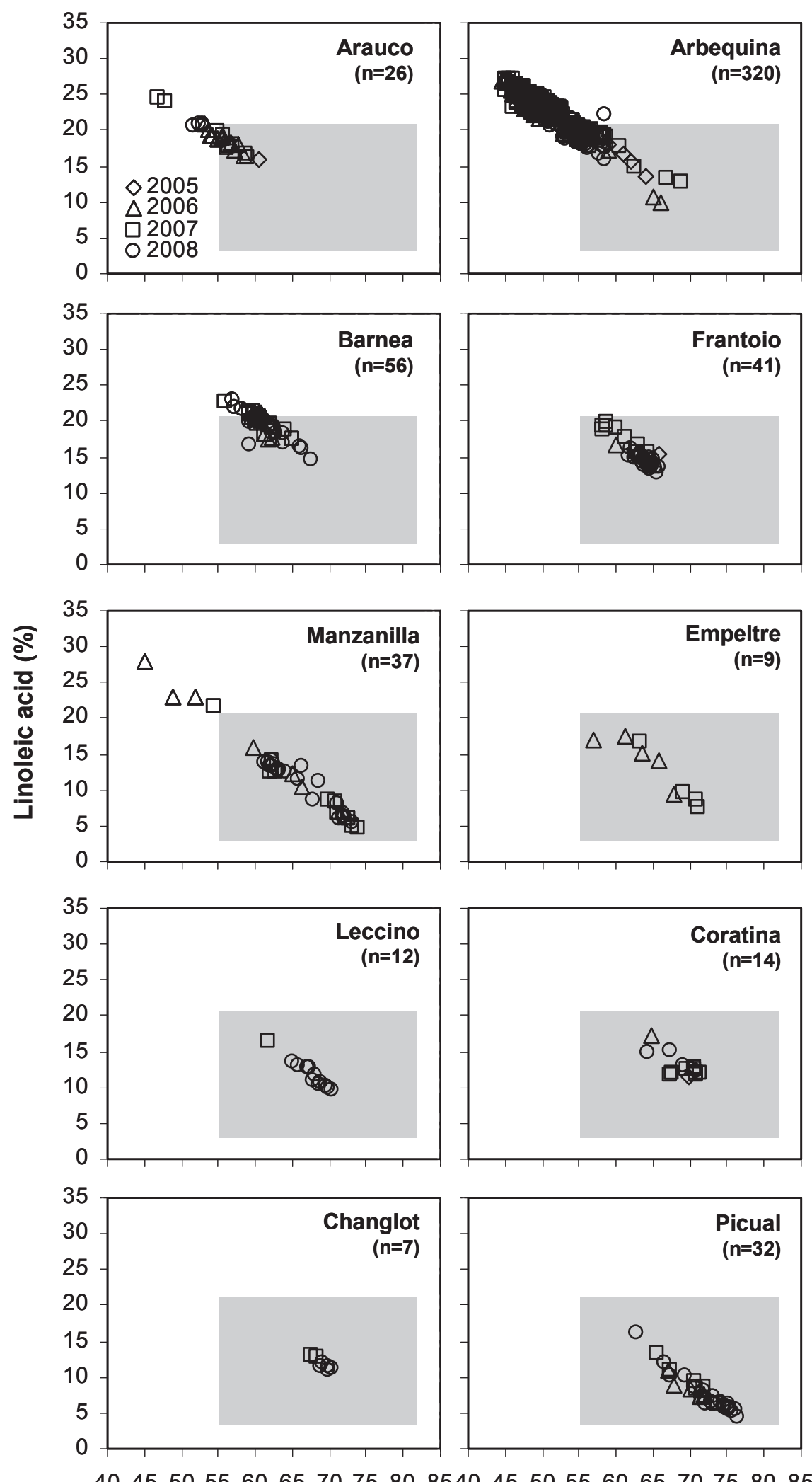

\section{Oleic acid (\%)}

Figure 1

Oleic and linoleic acid contents in olive oils from ten different varieties analyzed from 2005-2008 in the warm arid valleys of NW Argentina. The grey zone indicates the standard values accepted by the IOOC for virgin olive oil (oleic $55-83 \%$;

linoleic 3.5-21\%). Each data point represents one individual sample although high data density prevents identifying each point. 


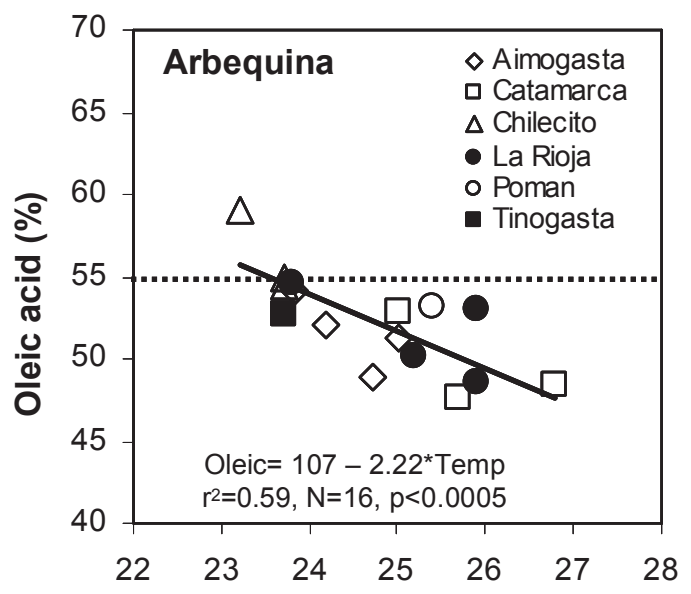

Seasonal mean temperature $\left({ }^{\circ} \mathrm{C}\right)$

Figure 2

Oleic acid content in Arbequina olive oils as a function of seasonal mean temperature at six different locations in the provinces of La Rioja and Catamarca, NW Argentina. Seasonal mean temperature is the average for the 5 months during the oil

accumulation period (December-April). Each point is the

average oleic acid content for each year by location

combination. Fitted linear regression is shown and the dotted line indicates the lower accepted limit of oleic acid by the IOOC.

\section{DISCUSSION}

This study characterized the fatty acid profile of olive oils produced by the olive industry in the Province of La Rioja over 4 years including olives grown and harvested in modern, mature monovarietal orchards over an extensive portion of NW Argentina. Fatty acid composition is one of the primary chemical parameters used to distinguish virgin olive oil from other vegetable oils. In this study, oleic acid contents showed a clear varietal influence, which permitted a ranking of major varieties into three categories for oleic acid contents when grown in NW Argentina: low (<55\%; Arbequina, Arauco), intermediate (55$65 \%$; Barnea, Frantoio), and high (>65\%; Manzanilla, Empeltre, Leccino, Coratina, Changlot, Picual).

Currently, Arbequina is the most commonly planted variety in NW Argentina because of its rapid growth and high productivity. For this reason, Arbequina represented 320 of the 563 samples analyzed in our study. The low values reported here for Arbequina are similar to those obtained from the province of Catamarca for younger orchards (Ravetti, 1999; Mannina et al., 2001; Matías et al., 2004; Ceci et al., 2004; Ceci and Carelli, 2007). The categorization of olive oil varieties by oleic acid content from this study (Table 5) may be useful for blending the oil of Arbequina with that of other varieties to meet the minimum IOOC requirements for virgin olive oil, and also to select a wider range of olive varieties with improved fatty acid composition for future orchards.

Four common olive varieties (Arbequina, Picual, Frantoio, Coratina) evaluated for differences in fatty acid composition between NW Argentina and the Mediterranean Basin all showed lower values of oleic acid and higher values of linoleic

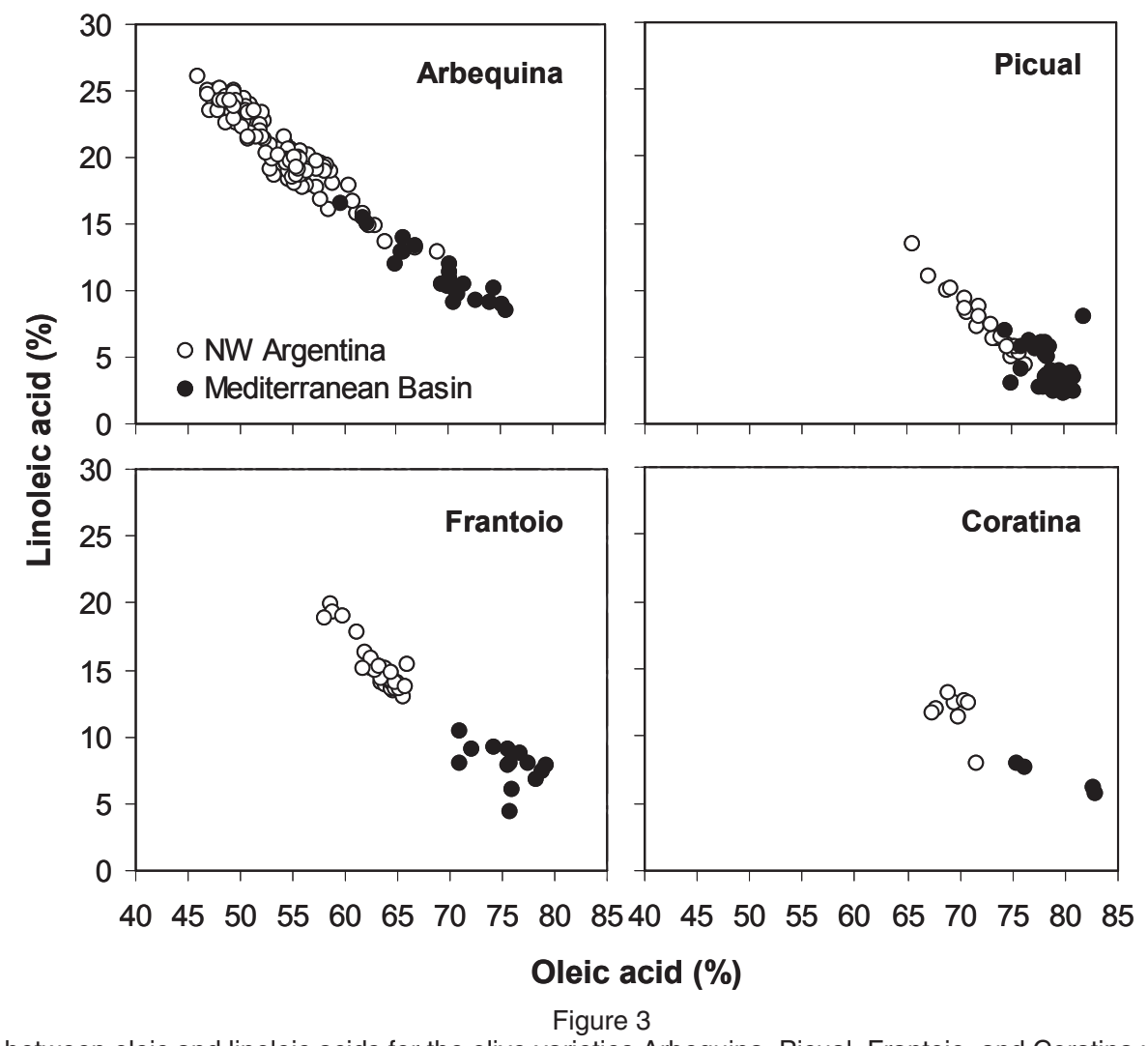

Relationships between oleic and linoleic acids for the olive varieties Arbequina, Picual, Frantoio, and Coratina when grown in NW Argentina and the Mediterranean Basin (Spain and Italy). Data are from this study and previously published literature (listed in Tables 1 and 3, respectively). 


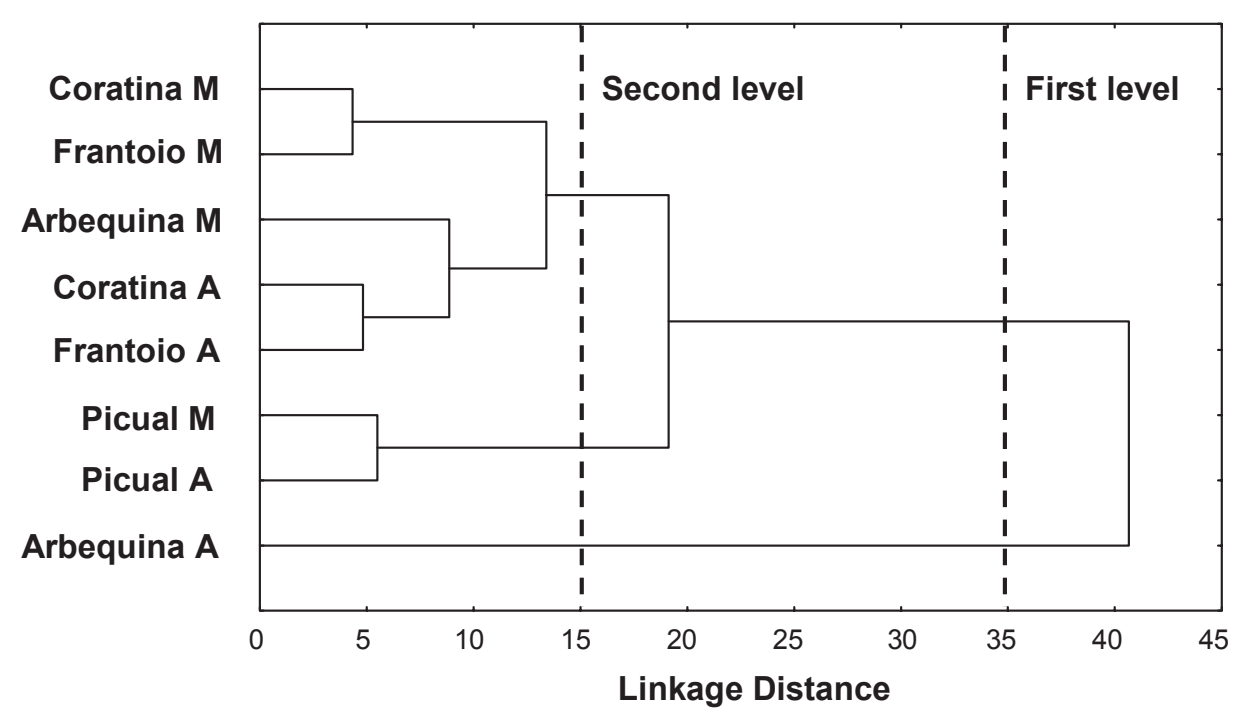

Figure 4

Dendrogram from the tree cluster analysis of fatty acid compositions for the varieties Arbequina, Picual, Frantoio and Coratina growing in NW Argentina (A) and the Mediterranean Basin (M). Data are from this study and previously published literature (listed in Tables 1 and 3, respectively). The dashed lines divide the dendrogram into different group levels.

acid in NW Argentina when combining results from our study with previously published data (Fig. 3). This suggests that lower oleic acid content in NW Argentina versus the Mediterranean is a general phenomenon. Lower oleic acid values have also been noted recently in the Spanish variety Arbequina growing in Central Argentina although the differences were not as pronounced (Torres et al., 2009). Of the varieties evaluated in our study, the Spanish variety Picual had a similar overall fatty acid composition in comparison to the Mediterranean based on tree cluster analysis despite having somewhat lower oleic acid values in NW Argentina. Thus, Picual may be an appropriate olive variety for the warm valleys of NW Argentina with an aim of increasing the area planted with varieties able to yield oils with high oleic acid. Also, the production of monovarietal blends using olive oil from NW Argentina and from more southern and cooler regions of the country (Ceci and Carelli, 2010 ) is an increasingly used commercial strategy.

The differences in fatty acid compositions between NW Argentina and the Mediterranean Basin are most likely related to a genotype $x$ environment interaction. Studying the seasonal patterns of fatty acid composition as has been done recently in southern Greece (Vekiari et al., 2010) would be a first step towards understanding the physiological basis of the varietal classification found in this study for the warm arid and semi-arid valleys of NW Argentina (Table 5). Preliminary results indicate that the low oleic acid values may be due to a continuous decrease in oleic acid content in Arbequina during fruit growth and oil accumulation, while other varieties such as Coratina and Picual do not show a pronounced decrease (Rondanini et al., 2008).
Other studies from different continents also indicate differences in oil fatty acid compositions compared to the european Mediterranean Basin and with respect to IOOC standards, especially for oleic acid contents in warm areas such as Tunisia, Turkey, and Iran (Nergiz and Engez, 2000; Sadeghi and Talaii, 2002; Dhifi et al., 2004; Manaï et al., 2007; Zarrouk et al., 2009; Diraman, 2010). Air temperature in NW Argentina can reach maximum daily temperatures of up to $5-10^{\circ} \mathrm{C}$ above that observed in Córdoba and Jaén (Spain) during many months of the year. Thus, the low values of oleic acid in NW Argentina could be related to high temperatures, as was recently suggested by Ceci and Carelli (2010). Supporting this hypothesis, a negative relationship between oleic acid content and seasonal mean temperature during oil accumulation was demonstrated for Arbequina in this study (Fig. 2). This model for Arbequina grown in La Rioja and Catamarca predicts that oleic acid content is below the minimum $10 O C$ accepted value of $55 \%$ with seasonal temperatures above $23.5^{\circ} \mathrm{C}$. However, the negative relationship between oleic acid content and temperature is contrary to the wellstudied effect of temperature on the oil composition of oilseed crops such as soybean, sunflower, and flax (Gunstone et al., 2007). In these species, higher temperatures during seed development result in higher oleic acid content values at the expense of polyunsaturated fatty acids. Potentially, metabolic differences in lipid metabolism between olive and other oil crops are responsible for these divergent results. For example, various studies have shown differences in the metabolic control of oil synthesis in olive and oil palm (Elaeis guineensis) (Ramli et al., 2002; 2005). Thus, olive may be an interesting alternative model to oilseed crops (Hernández et al., 2005). Manipulative, branch-warming 
experiments are currently being conducted in NW Argentina to better evaluate the proposed negative relationship between temperature and oleic acid content (García-Inza, personal communication).

\section{CONCLUSIONS}

This study indicates strong varietal differences in the fatty acid composition of olive oil from NW Argentina. The major varieties were identified as having low ( $<55 \%$; Arbequina, Arauco), intermediate (55-65\%; Barnea, Frantoio), and high (>65\%; Manzanilla, Empeltre, Leccino, Coratina, Changlot, Picual) oleic acid contents. The differences in oleic acid contents among varieties grown in NW Argentina and the Mediterranean Basin suggests a genotype $x$ environment interaction with some varieties such as Arbequina showing much lower oleic acid values in NW Argentina and others such as Picual being less affected. This response is likely to be temperature driven although further research is needed.

\section{ACKNOWLEDGEMENTS}

We thank Agro Aceitunera, Famatina Valley, Olivos Argentinos, Palas Atenea, Promas, Timbó, Vidagro, All Pack, Yovilar and Zait Shemen for providing oil samples; D Del Carril, G Mateos, C Pulido, K Goettlib, E Barbero and E Silva for technical assistance; S Catalá for statistical advice; and D Ruiz for developing the chemical techniques. $\mathrm{R}$ Savin and M Melgarejo gave useful comments on an early version of the manuscript and Eduardo García and Orlando Barros also helped at various stages of the study. Grants from Antorchas Foundation (14169/17), the Government of La Rioja and Cámara Olivícola Riojana (MICE-CORCRILAR № 130), and the Ministerio de Ciencia y Tecnología of Argentina (ANPCyT- PICT 32218, COFECyT - PFIP 121) supported this study. During the experiments, DR held a post-doctoral fellowship co-supported by Agro Aceitunera SA and CONICET.

\section{REFERENCES}

Aguilera MP, Beltrán G, Ortega D, Fernández A, Jiménez A, Uceda M. 2005. Characterisation of virgin olive oil of Italian olive cultivars: 'Frantoio' and 'Leccino', grown in Andalusia. Food Chem. 89, 387-391.

Ayerza R, Sibbett GS. 2001. Thermal adaptability of olive (Olea europea L.) to the Arid Chaco of Argentina. Agric. Ecosys. \& Environ. 84, 277 - 285.

Beltrán G, Del Río C, Sánchez S, Martínez L. 2004. Influence of harvest date and crop yield on the fatty acid composition of virgin olive oils from cv. Picual. $J$. Agric. Food Chem. 52, 3434-3440.

Bucci R, Magri AD, Magri AL, Marini D, Marini F. 2002. Chemical authentication of extra virgin olive oil varieties by supervised chemometric procedures. $J$. Agric. Food Chem. 5, 413-418.

Ceci LN, Carelli AA. 2007. Characterization of monovarietal argentinian olive oils from new productive zones. J. Am. Oil Chem. Soc. 84, 1125-1136.

Ceci LN, Carelli AA. 2010. Compositional data review of monovarietal Argentinean olive oils. In: Tomas MB (Ed) Advances in Fats and Oil Research. Transworld Research Network, Kerala, India. pp. 71-97.

Ceci LN, Santa Cruz MJ, Melgarejo M, Moro O, Carelli AA. 2004. Calidad de aceites de oliva varietales argentinos. Índices de calidad. Aceites y Grasas 57, 648-653.

Civantos L. 1999. Obtención del aceite de oliva virgen. $2^{\circ}$ ed. Ed. Agrícola Española. Madrid. pp. 316-319.

Dhifi W, Hamrouni I, Ayachi S, Chahed T, Saidani M, Marzouk B. 2004. Biochemical characterization of some Tunisian olive oils. J. Food Lipids 11, 287-296.

Di Giovacchino L, Mucciarella MR, Costantini N, Ferrante ML, Surricchio G. 2002. Use of nitrogen to improve stability of virgin oil during storage. J. Am. Oil Chem. Soc. 79, 339-344.

Diraman H. 2010 Characterization by chemometry of the most important domestic and foreign olive cultivars from the National Olive Collection Orchard of Turkey. Grasas y Aceites, 61, 341-351.

EEC 1991. Regulation on the characteristics of olive and olive pomace oils and their analytical methods. Official Journal of European Commission L248, 6-36.

Gunstone FD, Harwood JL, Dijkstra AJ. 2007. The Lipid Handbook. CRC Press. Boca Ratón, FL. 268 p.

Hernández ML, Mancha M, Martínez-Rivas JM. 2005. Molecular cloning and characterization of genes encoding two microsomal oleate desaturases (FAD2) from olive. Phytochem. 66, 1417-1426.

IOOC 2001. Preparation of the fatty acid methyl esters from olive oil and olive-pomace oil. International Olive Oil Council, Madrid http://www.internationaloliveoil.org/ estaticos/view/222-standards/ [on line Date 8/3/11].

IOOC 2006. International Oil Olive Council trade standard applying to olive oil and olive-pomace oil. International Olive Oil Council. Madrid. http://www.internationaloliveoil. org/estaticos/view/222-standards/ [on line Date 8/3/11].

MAGPyA 2010. Olivo, Perfiles Productivos http://www. alimentosargentinos.gov.ar/ olivicola/ [on line Date 8/3/11]

Mailer RJ. 2005. Variation in oil quality and fatty cid composition in Australian olive oil. Aust. J. Exp. Agric. 45, 115-119.

Manaï H, Haddada FM, Trigui A, Daoud D, Zarrouk M. 2007. Compositional quality of virgin olive oil from two new Tunisian cultivars obtained through controlled crossings. J. Sci. Food Agric. 87, 600-606.

Mannina L, Fontanazza G, Patumi M, Ansanelli G, Segre A. 2001. Italian and Argentine olive oils: a NMR and gas chromatographic study. Grasas y Aceites 52, 380-388.

Matías AC, Luna MC, Moyano PL, Alderete Salas S, Gómez PE, Dalla Lasta F, Benítez JL, Montalván LD. 2004. Determinación del momento oportuno de cosecha para la obtención de aceite de oliva virgen extra de las variedades Pendolino, Moraiolo, Picual y Arbequina cultivadas en el valle central de Catamarca (República Argentina). Aceites y Grasas 57, 676-681.

Morelló JR, Motilva MJ, Tovar MJ, Romero MP. 2004. Changes in commercial virgin olive oil (cv Arbequina) during storage, with special emphasis on the phenolic fraction. Food Chem. 85, 357-364.

Nergiz C, Engez Y. 2000. Compositional variation of olive fruit during ripening. Food Chem. 69, 55-59. 
Pardo JE, Cuesta MA, Alvarruiz A. 2007. Evaluation of potential and real quality of virgin olive oil from the designation of origin "Aceite Campo de Montiel" (Ciudad Real, Spain). Food Chem. 100, 977-984.

Ramli US, Baker DS, Quant PA, Harwood JL. 2002. Control mechanisms operating for lipid biosynthesis differ in oil palm (Elaeis guineensis Jacq.) and olive (Olea europaea L.) callus cultures. Biochem. J. 364, 385-391.

Ramli US, Salas JJ, Quant PA, Harwood JL. 2005. Metabolic control analysis reveals an important role for diacylglycerol acyltransferase in olive but not in oil palm lipid accumulation. FEBS 272, 5764-5770.

Ranalli A, Tombesi A, Ferrante ML, De Mattia G. 1998. Respiratory rate of olive drupes during their ripening cycle and quality of oil extracted. J. Sci. Food Agric. 77, 359-367.

Ranalli A, Sgaramella A, Surricchio G. 1999. The new "Cytolase 0" enzyme processing aid improves quality and yields of virgin olive oil. Food Chem. 66, 443-454.

Ravetti L. 1999. Caracterización preliminar de variedades y aceites de oliva vírgenes de la provincia de Catamarca. Aceites y Grasas 36, 361-369.

Ravetti LM, Matías AC, Patumi M, Rocchi P, Fontanazza G. 2002. Characterization of virgin olive oils from Catamarca and La Rioja, Argentina: general characteristics. Acta Horticulturae 586, 603-606.

Rondanini D, Castro DN, Hall AJ, Rousseaux MC. 2008. Contrasting patterns of oleic accumulation between olive cultivars growing in warm valleys of Argentina. In Proc. of the VI Symposium on Olive Growing, ISHS, Evora, Portugal. pp 89.

Sadeghi H, Talaii AR. 2002. Impact of environmental conditions on fatty acids combination of olive oil in an Iranian olive, cv. Zard. Acta Horticulturae 586, 579582.
Sánchez-Ortiz A, Perez AG, Sanz C. 2007. Cultivar differences on nonesterified polyunsaturated fatty acid as a limiting factor for the biogenesis of virgin olive oil aroma. J. Agric. Food Chem. 55, 7869-7873.

Torres MM, Maestri DM. 2006. The effects of genotype and extraction methods on chemical composition of virgin olive oils from Traslasierra Valley (Córdoba, Argentina). Food Chem. 96, 507-511.

Torres MM, Pierantozzi P, Cáceres ME, Labombarda P, Fontanazza G, Maestri DM. 2009. Genetic and chemical assessment of Arbequina olive cultivar grown in Córdoba province, Argentina. J. Sci. Food Agric. 89, 523-530.

Tovar MJ, Romero MP, Alegre S, Girona J, Motilva MJ. 2002. Composition and organoleptic characteristics of oil from Arbequina olive (Olea europea L.) trees under deficit irrigation. J. Sci. Food Agric. 82, 17551763.

Uceda M, Hermoso M. 2001. La calidad del aceite de oliva. In 'El cultivo del olivo'. (Eds D Barranco, R Fernández-Escobar, L Rallo). pp 589-614 (Junta de Andalucía- Ediciones Mundi-Prensa: Madrid)

Vekiari SA, Oreopoulou V, Kourkoutas Y, Kamoun, N, Msallem, M Psimouli V, Arapoglou D. 2010. Characterization and seasonal variation of the quality of virgin olive oil of the Throumbolia and Koroneiki varieties from Southern Greece. Grasas y Aceites 61, 221-231

Zarrouk W, Baccouri B, Taamall W, Trigui A, Daouda D, Zarrouka M. 2009. Oil fatty acid composition of eighteen Mediterranean olive varieties cultivated under the arid conditions of Boughrara (southern Tunisia). Grasas y Aceites 60, 498-506.

Recibido:3/12/10 Aceptado: $17 / 3 / 11$ 